\title{
PERMASALAHAN DALAM PELAKSANAAN SUPERVISI PENDIDIKAN TERKAIT SUMBER DAYA GURU DI SEKOLAH
}

\author{
Yani maisul fitria \\ yanimaisulfitria05@gmail.com
}

\begin{abstract}
ABSTRAK
Salah satu komponen yang berperan penting dalam tercapainya tujuan pendidikan adalah supervisi pendidikan. Supervisi pendidikan adalah suatu pembinaan sumber daya manusia yang ada pada pelaksana pendidikan (guru) untuk ditata sesuai dengan tujuan yang telah ditetapkan sesuai kesepakatan bersama dan dijalankan oleh supervisor pendidikan (pengawas dan kepala sekolah). Dalam rangka untuk mencapai profesionalisme seorang guru dalam menjalankan tugasnya maka perlu mengoptimalkan supervisi/pengawasan. Karena supervisi sangat berpengaruh besar dalam mencapai mutu suatu lembaga pendidikan. Dalam dunia pendidikan tidaklah selalu mulus, pasti ada rintangan dan problem yang dihadapi. Tujuan penulisan ini adalah untuk memecahkan dan menyelesaikan problem yang dihadapi.
\end{abstract}

Kata kunci : supervisi pendidikan, kepala sekolah, guru.

\section{LATAR BELAKANG}

Pendidikan merupakan suatu sistem yang terdiri dari beberapa komponen untuk mencapai tujuan pendidikan. Salah satu komponen yang berperan penting adalah pengawasan sekolah atau yang biasa disebut dengan supervisi pendidikan. Supervisi pendidikan dalam pengertian secara makro adalah suatu ilmu yang mempelajari bagaimana membina sumber daya manusia yang ada pada pelaksana pendidikan (guru) untuk ditata sesuai dengan tujuan yang telah ditetapkan sesuai kesepakatan bersama dan dijalankan oleh supervisor pendidikan (pengawas dan kepala sekolah). Penataan dalam hal ini mengandung makna mengawasi, memimpin, membina, atau mengontrol sumber daya yang meliputi perencanaan,pengamatan, pengawasan, dan pembinaan (Rahmat, 2013).

Dalam melaksanakan tugasnya, pengawas dan kepala sekolah bertindak sebagai supervisor mempunyai beberapa tanggung jawab yakni berkewajiban melaksanakan pembinaan administrasi sekolah yang bertujuan menciptakan situasi belajar mengajar menjadi lebih baik dan melaksanakan supervisi pendidikan yakni supervisi akademik sesuai dengan ketentuan yang telah ditetapkan supaya guru-guru termotivasi dalam menjalankan tugas-tugas dan mampu membimbing peserta didik menjadi lebih baik (Rahmat, 2013).

Perkembangan supervisi dewasa ini lebih menekankan kepada upaya guru untuk mengembangkan kualitas pembelajarannya melalui pengembangan keprofesionalan 
berkelanjutan. Sehubungan perkembangan pengetahuan dan teknologi yang berkembang pesat dalam waktu yang sangat singkat, supervisi dengan jumlah yang sangar terbatas dan dengan kemampuan yang variatif sehingga tidak mampu melayani kebutuhan supervisi guru dalam jumlah yang besar. Guru perlu berinisiatif menganalisis kualitas pembelajaran dan menemukan permasalahan untuk diupayakan peningkatan kualitasnya secara berkelanjutan. Supervisor lebih berperan sebagai fasilitator untuk terjadinya pengembangan keprofesionalan guru secara berkelanjutan tersebut. Disamping itu menumbuhkan motivasi guru yang sangat tinggi untuk selalu meningkatkan keprofesionalannya (Sabandi, 2013)

Dalam pelaksanaan tugasnya sebagai supervisor, pengawas dan kepala sekolah mengalami beberapa kendala. pandangan guru terhadap supervisi cenderung negatif yang mengasumsikan bahwa supervisi merupakan model pengawasan terhadap guru dengan menekan kebebasan guru untuk menyampaikan pendapat. Hal ini dapat dipengaruhi sikap supervisor seperti sikap otoriter, hanya mencari kesalahan guru dan menganggap lebih dari guru karena jabatannya. Dan juga guru senior cenderung menganggap supervisi merupakan kegiatan yang tidak perlu karena menganggap bahwa telah memiliki kemampuan dan pengalaman yang lebih.(Gunawan Imam, n.d.). Hal ini menjadi problem bagi supervisor untuk melakukan pengawasan kepada guru karena tidak mendapat respon dari guru tersebut. Seharusnya guru sangat antusias dalam untuk di supervisi agar guru dapat meningkatkan keprofesionalannya dan juga dapat meningkatkan proses pembelajaran menjadi lebih baik lagi sehingga tujuan pendidikan dapat tercapai secara maksimal. Oleh karena itu, dalam makalah ini penulis akan menyampaikan bagaimana alternatif dalam memecahkan masalah dalam pelaksanaan supervisi pendidikan terkait dengan sumber daya guru tersebut.

\section{Rumusan permasalahan :}

Bagaimana alternatif untuk memecahkan masalah dalam pelaksanaan supervisi pendidikan terhadap sumber daya guru di sekolah?

\section{Tujuan :}

Untuk memenuhi tugas mata kuliah dan untuk mengetahui bagaimana alternatif untuk memecahkan masalah dalam pelaksanaan supervisi pendidikan terhadap sumber daya guru di sekolah.

\section{PEMBAHASAN}


Kepala sekolah hendaknya dapat melaksanakan supervisi secara efektif. Sementara ini pelaksanaan supervisi di sekolah seringkali masih bersifat umum. Aspek-aspek yang menjadi perhatian kurang jelas, sehingga pemberian umpan balik terlalu umum dan kurang mengarah ke aspek yang dibutuhkan guru. Sementara guru sendiri pun kadang kurang memahami manfaat supervisi. Hal ini disebabkan tidak dilibatkannya guru dalam perencanaan pelaksanaan supervisi. Padahal proses pelaksanaan supervisi yang melibatkan guru sejak tahap perencanaan memungkinkan guru mengetahui manfaat supervisi bagi dirinya. Supervisi merupakan pendekatan yang melibatkan guru sejak tahap perencanaan. Supervisi merupakan jawaban yang tepat untuk mengatasi kekurangtepatan permasalahan yang berhubungan dengan guru pada umumnya.

Kepala sekolah diharapkan memahami dan mampu melaksanakan supervisi karena keterlibatan guru sangat besar mulai dari tahap perencanaan sampai dengan analisis keberhasilannya. Salah satu usaha untuk meningkatkan kualitas guru ialah melalui proses pembelajaran dan guru merupakan komponen sumber daya manusia yang harus dibina dan dikembangkan secara terus menerus agar dapat melaksanakan fungsinya secara profesional. Pelaksanaan supervisi yang diasumsikan merupakan pelayanan pembinaan guru diharapkan dapat memajukan dan mengembangkan pengajaran agar guru dapat mengajar dengan baik dan berdampak pada belajar siswa, serta guru pada dasarnya tidak membenci supervisi, tetapi tidak suka terhadap gaya supervisor. (Gunawan Imam, n.d.).

Jadi agar pelaksanaan supervisi dan pendidikan dapat berjalan dengan baik maka kepala sekolah dan juga supervisor harus melibatkan guru dalam perencanaan pelaksanaan supervisi agar guru dapat mengetahui manfaat supervisi baginya, dan juga gaya supervisor yang tidak otoriter sehingga dengan begitu guru tidak memandang negatif supervisi dan semakin termotivasi dalam meningkatkan keprofesionalannya, dengan begitu dapat berkembangnya pembelajaran tercapainya tujuan pendidikan.

\section{KESIMPULAN}

Permasalahan dalam pelaksanaan supervisi pendidikan terkait sumber daya guru di sekolah adalah rendahnya motivasi guru untuk di supervisi karena guru cenderung memandang negatif supervisi yang mengasumsikan bahwa supervisi merupakan model pengawasan terhadap guru dengan menekan kebebasan guru untuk menyampaikan pendapat dan juga guru senior cenderung menganggap supervisi merupakan kegiatan yang tidak perlu karena menganggap bahwa telah memiliki kemampuan dan pengalaman yang lebih, jadi disini di 
perlukan peran kepala sekolah dalam memahami dan melaksanakan supervisi pendidikan secara efektif.

\section{SARAN}

Kepala sekolah dan supervisi harus melibatkan guru dalam perencanaan pelaksanaan supervisi pendidikan sehingga guru tidak memandang negatif supervisi dan termotivasi dalam mengembangkan keprofesionalannya.

\section{REFERENSI}

Gunawan Imam. (n.d.). ALTERNATIF PEMBINAAN/SUPERVISI. 142-156.

Rahmat, S. (2013). Supervisi pendidikan. Tadris Jurnal Penelitian Dan Pemikiran Islam, 1(1), 1-18. Retrieved from http://stitmatuban.ac.id/wp-content/uploads/2015/10/TD1.3Supervisi-Pendidikan-H.-Sutrisno-Rahmat.pdf

Sabandi, A. (2013). Supervisi Pendidikan Untuk Pengembangan Profesionalitas Guru Berkelanjutan. Jurnal Ilmiah Ilmu Pendidikan, XIII(2), 1-9. 